\title{
MOBILE PHONE REVOLUTION IN THE TUNDRA? TECHNOLOGICAL CHANGE AMONG RUSSIAN REINDEER NOMADS
}

\author{
Florian M. Stammler
}

\begin{abstract}
This contribution looks at the influence of technological change that nomads in the Russian North have undergone, using as examples two crucial innovations: the snowmobile and the mobile phone. I argue that the snowmobile did not have the same revolutionary impact on the Russian tundra as it did in Fennoscandia, for reasons connected to long distances, infrastructure, spare parts, availability of fuel, priorities of Soviet transport policy as well as the convenience of previously used practices of herd control using 'sitting transport'. Different from that, I argue that mobile phones have the potential for a greater penetration into nomadic societies. Because they encourage equality rather than stratification, they are low maintenance; they are small enough to be embedded into existing social contexts. Connecting not only neighbours but the whole world, in principle, mobile phones may entail a significant socio-cultural change. The article presents first fieldwork evidence of such change among tundra nomads and relates this to existing theoretical studies on how mobile communication changes societies. Attention is paid to the particularities of a mobile type of communication introduced in mobile communities, that is, among nomads. In doing so, I explore similarities and differences in how technological change influences sedentary and nomadic societies.
\end{abstract}

Key words: industrialisation, mobile phone, nomadism, reindeer herding, snowmobile, technological change

\section{INTRODUCTION}

The broad introduction of the snowmobile and of other mechanised transport to remote Arctic communities of the Americas and northern Fennoscandia in the 1960s and 1970s has had tremendous influence on the livelihood of Arctic indigenous peoples. The consequences were more or less extensively studied in terms of the impacts on patterns of movement and settlement, subsistence economy, and cultural values in the Arctic. Notably, after a publication by Pelto (1987), in Fennoscandia the 'snow mobile revolution' has become a standard phrase to highlight the rapid economic and social change in the Arctic as a 
result of adopting new technologies. The introduction of the mobile phone, on the other hand, has not yet been a subject of study among northern nomads and/or reindeer herders. The discussion about technological change in the Arctic in general has relied only on studies in the western half of the Arctic. We still have a relatively poor understanding of what impact did technological changes exert on Russia's northern minorities; and nomadic societies, in particular, have not been intensively studied in terms of their response to the introduction of real-time mobile communication technology.

This paper starts to close this gap and reflect on the influence of technological change on indigenous northerners, mainly relying on fieldwork and personal conversations with representatives of European Northern Russia and West Siberia, carried out during 1998-2007. The evidence is rather anecdotal, since fieldwork was not focused on the topic of technological change, so that the insights gained were more a side-product of other work. Given the absence of better data, however, I aim to contribute a nomadic Russian view of what has been called the 'snowmobile revolution' in the West, and explain why the snowmobile did not have the same revolutionary impact on nomads of the Russian tundra and taiga that it had on the Sámi of Fennoscandia. I focus instead on the importance of mobile telecommunication, which emerged decades after the introduction of mechanised transport. I argue that its consequences might be reaching further than the snowmobile, which justifies the term 'mobile phone revolution', for several reasons. However, this material does not claim to be representative for the whole Russian Arctic, as East Siberia and the Far East are considered to be in a different situation due to their remoteness (Vitebsky 2000). However, other technology, such as TV, has also integrated that region into globally dominant value systems (Hoffmann-Novotny 1993), some of which generated overt or subtle resistance or led to new cultural variations in remote regions (Ventsel 2004). In fact, mobile phones seem to have a symbolic influence even in places where there is no network coverage yet.

The paper first introduces the background and the main academic works on the importance of snowmobiles and mobile phones with an emphasis on the latter. I shall then present fieldwork evidence on how snowmobiles and mobile phones have changed life in the tundra, and reflect upon the implications of these innovations for northern nomadic cultures. The discussion starts to relate this fieldwork material to other academic studies. Since it is impossible in this first paper to extensively review the applicability of existing theories on Russia, I shall focus on two main questions: 
a Why did the snowmobile fail to have the same revolutionary effect in Russia's north in comparison to Fennoscandia and North America?

b What are the first insights to be gained about the significance of realtime mobile communication for nomadic societies in the Arctic?

The conclusions and answers will be very preliminary and have the form of reflections and thoughts that should stimulate further research.

\section{BACKGROUND AND THEORETICAL CONSIDERATIONS}

In the Russian North, there has been a certain return to subsistence after the collapse of the Soviet Union (Ziker 2002) and in some regions full-time nomadism has broadly persisted (Stammler 2005). In that respect the region is very different from the Nordic countries and North America, and I shall show how the use of snowmobile has so far failed to have an influence of the same magnitude in my fieldwork sites in Russia. The possible consequences of the introduction of the mobile phone to tundra nomads, I argue, could be reaching further, because of its more principal difference from the previously available means of communication.

\section{Theorising snowmobiles}

For some the snowmobile represents a technological upgrade, which is based on the same principle: physically moving people or goods between locations, doing so only during the snow-covered period. "Physical muscles" (of humans or other animals) are being replaced by "mechanical muscles". This is another form of transport, but it is not principally different.

Studies about technological changes in the Arctic (e.g., Kemp 1971, Pelto 1987, Helander-Renvall 2007) highlight important impacts on indigenous northern communities that could not yet be seen happening in all Russian Northern regions. In this section, I will introduce the background of these changes and the findings of studies. I will then review some of the main existing works on the social impact of mobile communication and try to relate ethnographic material from northern Russia to these findings.

According to Kemp (1971) and Pelto (1987), mechanised transport as a revolutionary innovation in the Arctic led to the following major consequences: 
a The 'end of nomadism' of West-European reindeer herders is closely related not only to the 'snowmobile revolution', but to mechanised transport in general. In Fennoscandia, four-wheelers used during the snowfree season have acquired a similarly important function next to the snowmobile, because reindeer herders can afford to commute more often between their homes/families and their herd. The extensive work of monitoring tens of kilometres of reindeer fences in Europe would not be thinkable without mechanised transport. Along similar lines, Kemp (1971) had found very early that the hunting radius of Inuit hunters on Baffin Island had increased significantly as a result of mechanised transport. With this extended radius natives can afford to live more permanently with their families, while commuting to their hunting grounds/reindeer pastures. Prominent Sámi reindeer herding activists have regretted this detrimental influence on the 'nomadic culture' of their people. It was also highlighted that especially the young male generation were the driving force behind this change: they preferred to stay with their wives in permanent bases, and they are (as most young men) enthusiastic about new technologies (see also Helander-Renvall 2007: 30).

b Mechanised transport with its constant need for maintenance, and fuel, integrates Arctic subsistence communities more tightly into a global exchange economy. Forces external to the subsistence economy system become uncontrollable (see Kemp 1971). This created new dependencies in former Arctic subsistence communities, notably on energy-intake from non-local resources ('de-localisation', Pelto 1987). Nowadays the development of global oil and gas prices as well as the stability of different currencies has a direct influence on the household budget of hunting and herding families in the Arctic. The more expensive mechanised transport gets, the more herders and hunters are forced to engage in commodity production, rationalise their economic activity along Western economic considerations, and thus get into the "extensive spiral" described by Beach (1981) for Swedish reindeer pastoralists (for a discussion see Beach \& Stammler 2006).

Accrediting the changes only to the impact of mechanised transport is in my view overstating the case. Northern indigenous cultures have been changing long before the introduction of the snowmobile, and have proven to respond flexibly to innovations for centuries (Krupnik 1993, Stammler 2005). This capacity is also relevant in the light of recent rapid changes in the natural environment of the North (Rees et al. 2007). Such an innovation is the develop- 
ment of large-scale reindeer pastoralism itself (Krupnik 1993, Golovnev 1995, Vitebsky 2005).

Experts agree that the changes generated by these innovations cannot be undone, and a return to previous subsistence practices is no longer possible (Beach 1981). Pelto (1987) has found that even those Sámi who lacked the necessary mechanical devices borrowed snowmobiles and chainsaws from richer neighbours, rather than relied on manual energy. However, activists still regret this development and remember, for example, how their relations with reindeer were more intimate before these technological innovations. As a result, some play with thoughts of reintroducing a lifestyle with more mobility relying rather on reindeer transport and manual labour. ${ }^{1}$ On the other hand, Helander-Renvall (2007: 31) argues that for young herders the snowmobile serves as a tool for "learning more about the traditional ecological knowledge". The snowmobile becomes part of the Sámi cultural practices, which shows how ways of knowing the land among herders change with the introduction of new technology. This points to a notion of 'knowing' instead of 'knowledge'. Knowing is conceptualised as a process in constant transformation (Vitebsky 1995, Ingold 2000: 228ff, Stammler 2005: 215-217) rather than "traditional ecological knowledge" as a body of tradition rooted in the past that can be put into databases and "compared" with scientific knowledge, as popular notions suggest.

\section{Communication theory}

Evidence from other regions of our planet suggests that changes of the same magnitude or bigger than the adoption of snowmobile into use can be initialised by innovations that do not move people but spread information. These might substantially change processes of knowing, the ways how people learn and find out, rather than merely what they know. In this respect, the importance of television for global integration of values (Hoffmann-Novotny 1993) was groundbreaking. However, television is accessible mostly for people living in villages, where television signals can be received. The nomadic population of the tundra was exposed to television, and watching it became one of the main activities for tundra people during their time spent in villages. Television can be seen as one efficient vehicle of transporting Soviet culture to the remote outposts of the empire. However, besides being not portable enough for nomads, television had one fundamental shortcoming: communication was only one-way, and viewers could only receive, not send information. 
This is different for the radio stations that were crucial for setting up the Soviet reindeer meat processing industry in sovkhozes. They had arrived at Yamal in West Siberia during the time between the Second World War and the mid-1950s, and enabled the headquarters in villages to have real-time conversations with herders in the tundra. However, the quality of the connection was bad, connection was made only once a day at a specially assigned time, and installing the antenna was not always easy and required time and effort. Most importantly, however, these conversations were heard by the whole community and everybody else who tuned in. Therefore, strict regulations on contents and use were in place, so that this communication technology was only used for business-related issues. ${ }^{2}$

The mobile phone brought a form of communication into the tundra which principally had not been there before: it offered real-time interactive private oral communication, conveying information from place to place without moving people. Differently from the previously available radio station, mobile communication offers privacy and confidentiality. Before, this capability was attributed only to shamans, who could let their souls travel to different locations and bring back advice or information without physically having to move. As Katz and Aakhus (2002a: 2) note in their introduction, not even all divine beings had that capability, as the Greek gods used the messenger Hermes for communication. Therefore I argue that the introduction of mobile phone communication to the tundra, which is now under way in Russia, marks possibly the most far-reaching innovation reindeer herders have ever seen, and we are only at the very beginning of witnessing its consequences.

Researchers in other regions have noted the exceptionally rapid pace of mobile phone distribution once the technology arrived to a region (Wajcman 2007), and the tundra regions of Russia seem to confirm this. However, studies on the social and cultural consequences did not follow the rapid pace of mobile phone dissemination. Russia had in 2005 the fourth largest mobile phone subscribing community worldwide (85.5 million according to Gladarev 2006), which makes the lack of studies on its social implications even more remarkable. Exceptions are the short articles by Vershinskaia (2002) and Gladarev (2006), which are both positioned in the metropolitan setting of St Petersburg and Moscow, and quote only Western studies in the lists of references.

A very thorough attempt to theorise about mobile communication in general is Katz's and Aakhus's (2002a) edited volume containing national and comparative case studies as well as behavioural and psychological works on mobile phones. Particularly important for the analysis in respect to generation is Nawfus \& Tracey's (2002) contribution to the volume on mobile phones chang- 
ing people's personhood. They identified the predictable enthusiasm to mobile phones among teenagers in England, but the fiercest opposition came exclusively from the group under 30 years old. This is because they base their identity more on reflexively creating their own worlds of consumption, and if they were to use mobile phones like any teenager, they might feel their self-esteem, identity and distinctiveness called into question (Katz \& Aakhus 2002b: 219).

Katz and Aakhus (2002a) aggregate the insights of their case studies into a general theory of mobile communication which they call Apparatgeist. They argue that there are general principles on how people interact with technologies that are independent of individual creativity and cultural diversity (Katz \& Aakhus 2002a: 310), which makes one curious if this would hold for Arctic reindeer nomads as well. For them, Apparatgeist encompasses both the functionalist approach to a technological innovation, its use as a tool for achieving a goal, and the approach of structuration theories (Giddens 1986, Katz \& Aakhus 2002a: 315) that "emphasize process at the expense of values that animate processes". As anthropologists we share an appreciation of values and how they shape processes, but to my view the link goes also the other way round: values animate processes and processes shape values. The authors do not appreciate enough the dynamically changing nature of values, in the sense that values themselves are processes. In nomadic societies such as the Nenets, we can see particularly well how processes, here movement, shape values at least as much as values shape processes (Stammler 2005: 334ff).

Geser's Towards a Sociology of the Mobile Phone (2004) is another general theoretical piece about mobile phones. His argument opposes that of Katz and Aakhus in that the global popularity of the mobile phone will rather not cause worldwide convergences and homogenisation because it allows for such a large diversity of uses and is "more likely to accentuate differences rather than communalities between various population segments, social institutions or ethnic cultures" (Geser 2004: 42). In this point Geser is less in line with the Apparatgeist theory than with the structuration theorists, arguing that once a technology becomes accepted within the community, its novelty fades out, it becomes invisible and does not change the relationship that people want to have with others.

Other studies on the mobile phone have a more regional character, many of whom focus on the Nordic countries, with Finland being at the forefront of mobile phone popularity. Some studies suggest generally relevant findings, such as Kopomaa (2000) on Finland, looking at the privatisation of public space and individualistic networking through the mobile phone, and Lemish and 
Cohen (2005a) on the gendered nature of mobile phone uses. The same authors (2005b) contribute to the broader topic of mobile phones, fashion and expression of identity in an edited volume by Ling and Pedersen (2005). That volume is less relevant for our analysis here, since many contributions compare the mobile phone with other technological innovations, none of which have found their ways into the tundra, or the use of mobile phones in crowded urban public spaces. A similar focus can be found in one of the few studies on Russian mobile phone users, where Gladarev (2006) found that the use of mobile phones among young people in St Petersburg is rather gender-neutral, whereas the discourse and meaning of the mobile phone is highly genderspecific.

The first in-depth anthropological study of the mobile phone by Horst and Miller (2006) is based on ethnography in Jamaica. The main finding of this study is that the use of mobile phones has different consequences in poorer communities, the most relevant ones being the use of these devices for getting money out of your network (rather than making money through mobile phone business), and the maintenance of very broad but shallow social networks that exist only because of the mobile phone, which is maintained through very short calls. Poor people maintain these networks in order to deepen particular contacts when there is a need.

Having introduced these basic theoretical lines along which the social importance of the mobile phone is analysed, I shall elaborate in my discussion more about what makes the advent of mobile communication in the tundra different from the introduction of snowmobile and mobile phone in sedentary societies.

\section{THE INFLUENCE OF MECHANISED TRANSPORT ON NOMADIC REINDEER HERDERS}

Snowmobiles went into production in the Soviet Union a decade after they had revolutionised the European and American North. A Soviet factory in Rybinsk created their main snowmobile called Buran on the basis of the early Bombardier Ski-Doo Alpine 640E of 1967, one of the very few Western snowmobiles with two tracks and one front-ski (Ksenofontov 2007). This forefather of Buran was originally designed in Canada as an engine for working in the forest, pulling heavy loads (hence, the two tracks), and being easily navigable through branches on the ground that would slide right and left of the single front ski without slowing down the vehicle. ${ }^{3}$ Burans were introduced in the tundra in a 
time of increased stability at the middle and end of the $1970 \mathrm{~s}$, when the Soviet system had established itself and the state reindeer herding and hunting industry provided stable income for the nomadic tundra population.

However, the emphasis of the Soviet-planned agricultural industry, of which herding and hunting in the Arctic was a part, was not as much on mechanised transport for individual herders as on general modernisation according to a master-plan for the whole country. An extensive programme launched in the county to settle down the nomadic Arctic population (perekhod na osedlyi obraz zhizni, 'transition to sedentary lifestyle') was supported by large-scale mechanised transport provided by state structures. Considering the large distances of the northern expanses of Russia, airplanes (the famous AN 2 biplane) and later helicopters (most notably the MI 8) made it possible to introduce work shifts for herders and hunters, having them work for a certain period in the tundra with the animals (e.g., 1-2 months), and then flying them back to the villages, from where the next work shift was flown in to replace them. This shift-herding was practiced in a number of reindeer herding collective farms in the Nenets Autonomous Okrug of northwestern Russia, and other regions such as Murmansk, and partially Chukotka, and led to the alienation of herders from the tundra. Fieldwork carried out during 2003-2005 revealed that even after the collective farms could hardly or not at all support this costly practice, reindeer herders regarded the tundra mainly as their workplace and the village as their home.

In other regions, aviation was more often combined with mechanised ground transport for reorganising labour in the tundra according to Soviet state agricultural-industrial plans. In Chukotka as well as on the Kola Peninsula, work shifts were organised with the use of passenger tanks (vezdekhods). These vehicles were also used for camp migration, bringing herders with their households on to new installations functioning as intermediary camps between the villages and the tundra pastures (prombaza). In these regions, scholars have highlighted the far-reaching negative legacy of these technological changes, because their maintenance became unaffordable, resulting in a collapse of reindeer herding in Chukotka (Krupnik \& Vakhtin 2002) and a state of stagnation and agony on the Kola Peninsula, where the old half-broken Soviet vezdekhod symbolises the whole state of the northern rural economy (Konstantinov \& Vladimirova 2006).

Vitebsky (2002) highlighted the social-cultural and spiritual consequences of this mode of production supported by aviation in the Sakha Republic: The tundra became a mainly male space, as men were the workers of the tundra, while women stayed in the villages, caring for children and working in the 
welfare sector. This gender aspect of modernisation leaves still much scope for further investigation, in particular in relation to the influence of technological change and innovation in the north.

Common to these developments is that mechanised transport influenced the former northern subsistence economies in Russia in a top-down manner, as a tool of the centralised planners to turn the tundra ranges into a giant open-air meat factory and nomads into workers of the 'agro-industrial complex' (agropromyshlennyi kompleks). Therefore, the snowmobile was not the driving force of technological change in the eastern half of the Arctic, even though it was present from the 1970s onwards. It was just that the Soviet emphasis was not on providing individualised mechanised transport for the tundra population. The socio-economic change in Russian northern hunting and herding did not happen on the initiative of the tundra people themselves, because the real winner in large-scale mechanisation was the Soviet agricultural industry rather than the people. Consequently, it was the Soviet agricultural industry that later started to provide (and in some places still does) snowmobiles for the collective use by their herding workers' teams, the brigades. They use the snowmobile collectively, whereas in Fennoscandia it is individually owned. Even nowadays among private herders, when there are several snowmobiles in a household, I have heard herders referring to them as collectively owned. For example, "our household owns three Burans", instead of "my father has a Buran, I have one, and my brother has one".

However, this does not mean that the snowmobile is unimportant for reindeer herders. Especially once large-scale mechanisation of the tundra economy was accomplished, tundra nomads began to understand the convenience of smaller mechanised transport. For reindeer herders in the West-Siberian tundra, the snowmobile has become the most important vehicle for two purposes: for the supply of staple food during spring and autumn, and for socialising, visiting friends, and negotiating contracts. Especially in April, reindeer herders stock supplies for their whole households to live autonomously until November. Several tons of supplies are usually brought by snowmobile from town to the camps. The snowmobile has made the visits of herders to the villages and towns more frequent and longer in duration: with reindeer transport, herders could only stay for a maximum of 24-36 hours in town, before they had to lead their animals to pastures for feeding. Many fieldwork informants have mentioned how convenient it is to not have to "feed" (refuel) one's means of transport every day while it is not moving.

However, this very "feeding" of the snowmobile with petrol and spare parts is at the heart of Pelto's 'de-localisation' and dependency argument in connection to the snowmobile revolution (1987). The energy needed for "feeding" and 
maintaining the snowmobile is not locally available, and has to be bought with cash, putting pressure on the productivity of the herding business. This is why many herders in Yamal have mentioned to me the advantages of reindeer:

You don't need to refuel this transport - fuel is growing on the pastures around you. And if you break down on the way with this transport, you can eat the broken part (i.e., one reindeer), and drive on with the rest (that is, the remaining deer in harness). You can also wear this transport, or cover your house with it (that is, its skin), and you never spend money on spare parts. (Nikolai Pyrerka, Yar-Sale tundra, 2006)

Most importantly and differently from the situation in Fennoscandia, mechanised transport has not taken over reindeer or other muscle-powered transport in Russian reindeer herding. Particularly for nomads with long migration routes or in mountainous terrain, snowmobiles do not fit the herders' needs, and are rarely used for work. One reason for this might be that the use of reindeer transport in combination with herding dogs is highly developed and successfully applied in reindeer herding in Russia, at least in the whole area west of the Yenisey River. In contrast, Helander-Renvall (2007) notes that before adopting the snowmobile the Sámi in Finland ran on skis to watch and round up their herds. ${ }^{4}$ Therefore, the snowmobile offered to these herders a means of transport where one can sit comfortably and approach the herd something that Nenets herders already could do on their sledges pulled by reindeer teams. However, some Nenets nomads have reported that their colleagues who have to cover shorter distances use snowmobiles for migration:

They come asking us to sell them sledges in return of fish. They do not have time and skills anymore to make reindeer sledges because they are busy repairing their snowmobiles all the time. And they need fish to sell for cash. (Alexandr Serotetto, Yar-Sale tundra, 2007)

Such people are often tundra residents, whose main source of income is fish rather than reindeer. Many of them plan to increase their reindeer headcount, using the snowmobile for ice-fishing on the Ob River, exchanging fish for live reindeer and building up a herd to lead a nenei-ilgnana, 'real life' with nomadic mobility (Khariuchi 2001, Stammler 2005). As long as they rely mostly on fish, they extensively use the snowmobile, especially for fishing on big lakes, deltas or bays. There the same advantage of the snowmobile counts as in villages: you do not have to refuel it when it is not used, and feeding reindeer while fishing on the ice is impossible.

Even though most of these examples stem from the Yamal-Nenets of West Siberia, evidence from fieldwork among their European neighbours confirms 
that as of 2007 the reindeer-centred way of life is still completely viable without the snowmobile, but not necessarily without helicopters and vezdekhods. In mountainous areas such as the Polar Urals, or the Verkhoiansk ridge in Sakha, the snowmobile is not suitable for covering steep stony ridges (Vitebsky 2005: 206ff). Moreover, small four-wheelers providing mechanised transport to western herders in the snow-free season have not been broadly introduced anywhere in the Russian North.

The image of Russian herders being conservative and opposed to broad acceptance of innovations in their economy would be totally misleading, as I shall show in the discussion about 'mobile phone revolution' below. Moreover, the snowmobile has been more broadly accepted in some regions of the Russian North than in others, for example in the Murmansk Oblast. Rather than challenging the overall argument, this underlines that in the rest of the Russian North the conditions for a broad acceptance of the snowmobile were not favourable. The Murmansk Oblast is the first industrialised northern region in Russia, and infrastructure there resembles much more the neighbouring Fennoscandia than the rest of the Russian North. Murmansk has several big cities, railroad and road connections to St Petersburg and Moscow, and a high density of villages and towns. Therefore, spare parts and fuel are more easily accessible than anywhere else in the Russian North. Moreover, the type of reindeer herding practised in Murmansk resembles the Sámi system in Fennoscandia rather than the close-herding practice in large parts of the Russian North. On the other hand, the different orientation of the state reindeer herding policy in Russia was crucial, and this explains why large mechanised transport vehicles (vezdekhods) were even more important than the snowmobile, at least during the Soviet times, if not until today (Konstantinov \& Vladimirova 2006).

It is interesting to reflect upon the fact that the frequent snowmobile use among herders in Russia might affect their judgement and ways of knowing their environment. For example, some have started to judge the quality of snow differently, along similar lines as Helander-Renvall (2007: 31) has reported about Finnish Sámi herders: As a rule, all herders judge first and foremost the snow quality as enabling or restricting reindeer access to pastures. Often the 'best' snow for the reindeer is 'bad' for transport, both mechanised and muscle-powered, so there are competing needs: sledges as well as snowmobiles are more difficult to drive in soft, loose snow, which is good for reindeer to dig through in search for lichen. Transport is best on hard, solid snow, ideally on ice crust, which is the worst for reindeer grazing. The speciality of snow suitable for snowmobile transport is, however, that twigs, branches and junk are rendered invisible in deep snow and the only ski of the Soviet Buran 
can get stuck in them and disintegrate. Snow which is too soft is bad because it does not 'carry' the snowmobile, and too little snow is bad because of hard frozen bumps are dangerous for drivers and passengers, as well as may damage the machine. ${ }^{5}$ Therefore, herders keep repeating the greater reliability of reindeer, although acknowledging its inferiority in speed. Usually they use a well-known proverb for expressing this: Tishe edesh - dal'she budesh, meaning 'drive more slowly and you get further'.

The loss of autonomy as a result of the snowmobile revolution is one of Pelto's important arguments (1987). The experiences of many herders of the collapse of the Soviet Union were related to an opposite pressure: with the loss of large mechanised transport subsidised by the state (helicopters, vezdekhods), reindeer herders were forced to rely on subsistence resources more strongly than before, including reindeer transport. This, however, cannot be taken as an argument for nomads' isolation from the outside world. As Khazanov (1994) has convincingly shown, any nomadic community has interacted for many centuries with other surrounding societies. This is particularly true for the young generation in the tundra, being exposed to Russian-style school education, staying for many years in villages, becoming part of an increasingly globalised youth through mainstream technological change and value-integration. Among these people the snowmobiles are the most popular, and serve to establish and maintain social networks through extensive visiting of relatives, friends and neighbours on the tundra. In spring, young men driving from camp to camp on snowmobiles are a frequent phenomenon, and the social and leisure-purpose of these visits is at least as important as the trade or barter exchange taking place during these visits. However, as I shall show below, the latest and most important field of these homogenising processes is connected to the introduction of mobile communication to remote areas such as the Russian tundra and taiga.

\section{THE INTRODUCTION OF MOBILE COMMUNICATION TO THE TUNDRA}

Let me start with the example of the Yamalo-Nenets Autonomous Okrug (YNAO) and my own experience as a witness of a 'mobile phone revolution'. Having conducted fieldwork during the same years provides the opportunity to track the processes step by step, and their influence on remote communities in the tundra. An ethnographical study of these processes gives insights into the social change and the importance of generation. 
When I came to Siberia for fieldwork in 1998, I did not possess a mobile phone myself, and their popularity was not yet very broad in the West among those with whom I communicated. Two years later, in summer 2000, they had introduced pagers in Salekhard, the okrug capital of the YNAO. Pagers were the entry into the world of mobile communication, but these devices could only receive, not send messages. For sending, one had to call a call centre and tell the operator the message over the phone. In the same summer, I was Salekhard's first Internet customer without a permanent residence and a telephone landline. There were no Internet cards yet on sale, but the regional phone operator issued one especially for me, which allowed me to connect by modem from any telephone. In the remote northern village of Se-Yakha, a stateof-the-art school with large computer rooms had opened that autumn, where children of reindeer herders who spend their first six years of life exclusively on the tundra in a mostly Nenets-language environment should be taught the use of Internet as a source of information (and entertainment). However, neither in Se-Yakha nor in most other small villages of the YNAO there were reliable phone landlines. It was possible to call only to the municipal centres (raionnyi centr), but hardly beyond. Therefore, the young generation of reindeer nomads in school could not yet use the Internet.

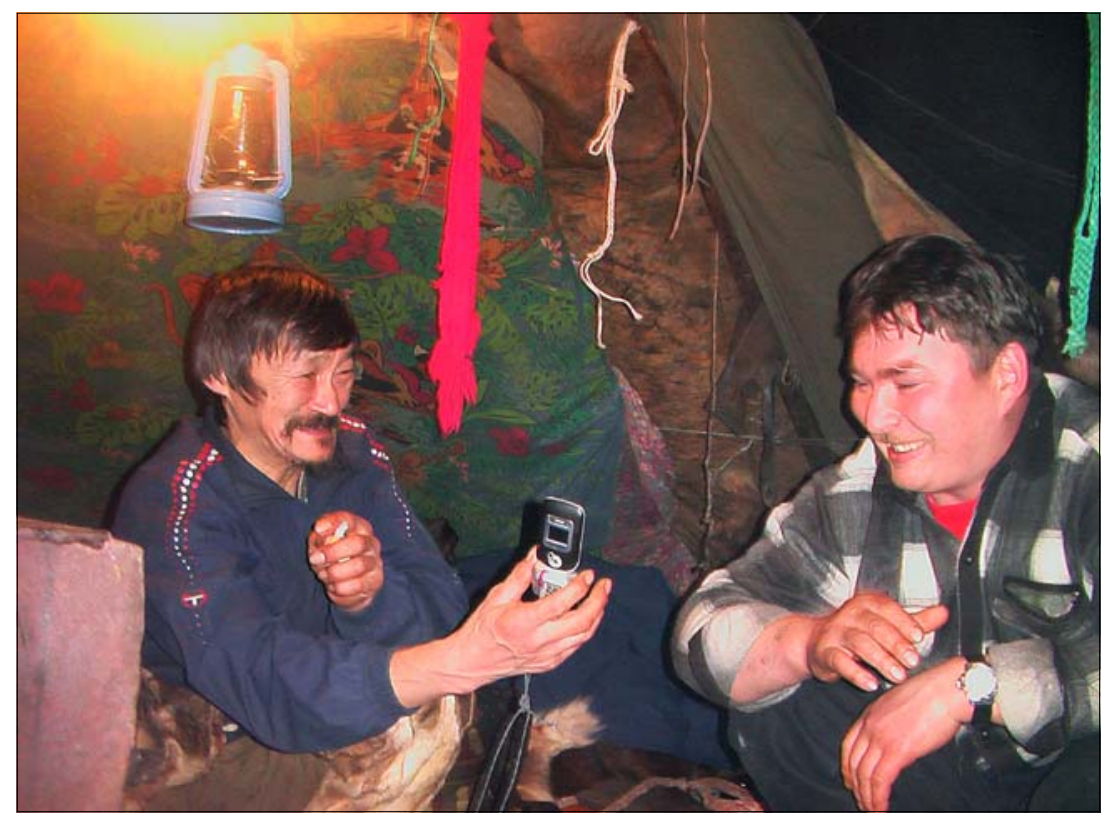

Figure 1. Extended use of mobile phones, enabling dialogue between generations. 
One year later, coming back from the tundra, Internet cards were on sale in the main phone office in Salekhard, and the operator was busy bringing Internet out to the first villages. Se-Yakha came straight into the digital age, whereas one year before it had not even been possible to send a telegram in Latin letters, except from the meteorological station.

All these advances in telecommunication were restricted to settlements, and nomads could find out about them only by travelling to the villages - on reindeer, by vezdekhod, helicopter or snowmobile. During the same period another device of mobile communication, not among people but between people and satellites, had been introduced to the tundra: all helicopters were equipped with GPS devices that enabled landing on exact locations even in bad visibility. The problem was and still is, however, that nomadic camps on the tundra are either not equipped with GPS devices and cannot send their location to pilots, or they are not using the devices because they themselves do not need or trust them, as I have seen in the Yamal and Bol'shezemel'skaia tundra.

The same year, in 2001, I found out that Yuri Vella, a famous Forest Nenets activist with whom I had stayed for a month in the Varegan taiga, got mobile communication right in the forest. Thanks to the oil company operating the Povkh oil field, this and other bits of taiga in the Khanty-Mansiysk Autonomous Okrug got mobile phone coverage, when in the capital of the YNAO people just got into using pagers. Yuri Vella had just got into deep trouble with the oil company on his hunting, fishing and herding grounds on environmental and human-rights issues (Collective authors 2000, Samakhova 2001, Niglas \& Toulouze 2004: 97, footnote 105). Ironically he used the very mobile infrastructure set up by the oil industry to link with western NGOs and Russian advocacy in order to lobby against this industry. In early 2001 the court case of the oil company against Vella was still ongoing, and it felt almost like from another world to sit in a Moscow apartment and talk to a reindeer herding activist in the taiga. Such an impression led me to first thoughts about the broad impact of mobile communication in the tundra.

While these were the beginnings, the last five years brought a massive influx of mobile communication to the tundra and taiga, at least in the area between Murmansk and the Yenisei River in Siberia. Mobile phone coverage reached Salekhard first in June 2001, and arrived at the Yamal Peninsula on 10 April 2004, as Sergei Baryshnikov, a friend from Yar-Sale, exactly remembers. Then almost the entire population of Yar-Sale, the administrative centre, had entered the age of mobile telecommunications within a year. Reindeer herders started to buy mobile phones and used them during their short stays 
in the village and as long as their herds and camps stayed in the catchment area, stretching around $15 \mathrm{~km}$ beyond the village. On the other side of the Ural Mountains, the European Nenets nomads of the Malozemel'skaia and Bol'shezemel'skaia Tundra could first use their mobile phones in the tundra in 2005, when they migrated closer to the villages, such as the Krasnoe village where there is a transmission tower. That tower also served the neighbouring village of Nel'min Nos. The policy of the main mobile phone operator was that every village with more than 1,000 inhabitants was to have a connection. In the Nenets Autonomous Okrug (NAO), most villages are below that threshold. ${ }^{6}$

\section{CASE STUDY: MOBILE PHONES AMONG VARANDEI HERDERS}

In the Nenets Okrug, a real revolution occurred in 2005 when mobile phone coverage was extended to the Varandei area, where oil is extracted by a Russian-American joint venture and shipped from a terminal in the Barents Sea to Europe and the U.S. This was done on the initiative of the oil company, as was the case in other oil settlements, such as Yuzhnoe Khylchy-Yu or Khariaga. Each of these phone transmission towers has a catchment area of about 20-30 $\mathrm{km}$. When I visited the Varandei area for fieldwork seven months after the introduction of the mobile phone, every nomadic household in the catchment area was already connected.

The small energy need of the mobile phones were covered by small mobile power generators which spread among herders years before the phones themselves and are mainly used for lighting in the camps. Phones are carried under the malitsa (Nenets reindeer parka) close to the body, which protects batteries from the cold in winter. SIM cards were purchased on a pre-paid basis, so herders did not fall into debts due to high charges. Topping-up the phone cards posed a problem, as friends or relatives in the village of Krasnoe had to go to the operator's office and pay cash to the reindeer herder's account. In order to ask your relatives to do so, you had to have at least enough money left to call them and tell them to top up. By summer 2006 this system worked quite well, and some herders had developed a good feeling of how much money they were ready to invest for their new connectivity.

Nazar, the head of the camp No. 2 of the private herders' union 'Erv', ${ }^{7}$ with whom I stayed in summer 2006, told me that he thought 250 roubles ( 7 EUR) per month was enough for the most urgent things to discuss. He also said he wanted to restrict himself, because "den'gi tam voobshe vyletaiut bystro" ('money is "flying" or running out quickly there'). He uses the mobile phone to receive 
news from the village, where his daughter goes to school, and to talk to his neighbours in order to coordinate the use of pastures and prevent mixing of the herd.

His sister Elena had a different view on mobile phones. She had just bought a fancy red folding phone, which would wake us up with its alarm function in the morning. She called to the village and the neighbours; there was a lot for chatting, exchanging news. The most popular start of a phone talk of this kind is "Chio delaesh'? ('What are you doing at the moment?') which is really an invitation to chat about everything and nothing. Elena made a very interesting observation about how mobile phones might change social relations in the tundra, "Ne o chom razgovarivat', kogda v gosti priedesh $k$ sosedam" ('There is nothing to talk about when you visit your neighbours'). This statement struck me as one with huge potential influence, since visiting each other for the purpose of exchanging news used to be one of the most important social activities in the tundra.

Indeed, the tundrovaia pochta or 'tundra post' had been famous for many decades, if not centuries, since reindeer herders were first contracted to bring mail on reindeer sledges to the remote settlements of the Russian North. Nowadays tundra-dwellers often stop at camps along their way when they travel, exchange news, have a cup of tea, some food and let their reindeer rest before they travel on.

Elena explained further that this excitement when visiting people after a long period had somehow gone, since now they could talk every day. Although she definitely did not mean to complain about the negative impacts of mobile phones, her thoughts are telling about possible cultural implications. A means of distance communication might reduce live communication. While Gladarev (2006) has described the mobile phone for young urban women in St Petersburg as a means of inhibiting possible communication, in the case of tundra it is not deliberate inhibiting, but a possible decrease of face-to-face contact in the future. This might also result in the decreased mobility of people on the tundra in the long run, and when people travel less, their ways of knowing the land will change.

All in all, however, reindeer herders evaluate the advent of mobile phones overwhelmingly positive. One herder said, "You can be out with the herd and tell your wife, 'I'm coming home now, heat the stove and brew some fresh tea". Two young herders travelled from their camp outside the mobile network catchment area to the slaughter corral of the camp within the catchment area, in order to help out and get some of their own reindeer back. Their travel time was ten hours on reindeer, and as soon as they had entered the catchment area they announced their arrival. While that enabled the host 
camp to prepare for their visit, on the other hand the pleasant element of surprise and excitement to see neighbours after a long time had disappeared. Nonetheless, planning security and shortcutting information flows for business is positively evaluated. I witnessed, for example, how the reindeer herding union's headquarters and the herding camps coordinated slaughter plans, time frames, supplies, and the delivery of meat to the settlement of Varandei to the oil company, all on mobile phones.

Coordinating and collecting information is also the rationale behind another case on the northern Yamal Peninsula, where the chairman of the herding obshchina ilebts ${ }^{8}$ intends to provide satellite phones to his herders in order to coordinate veterinary services, and collect information for insurance companies that ensure reindeer herds and the lives of herders.

I witnessed another novel extended use of mobile phones in 2007 with monitoring of environmental impacts of industrial development in the tundra. They make use of the extended technological capacity of modern phones which reaches beyond voice communication. Reindeer herders on duty with the herd during day and night travel frequently across oil installations, drill sites, wells, abandoned infrastructure, crossing pipelines or travelling along these. During these travels they immediately notice every change and also instantly con-

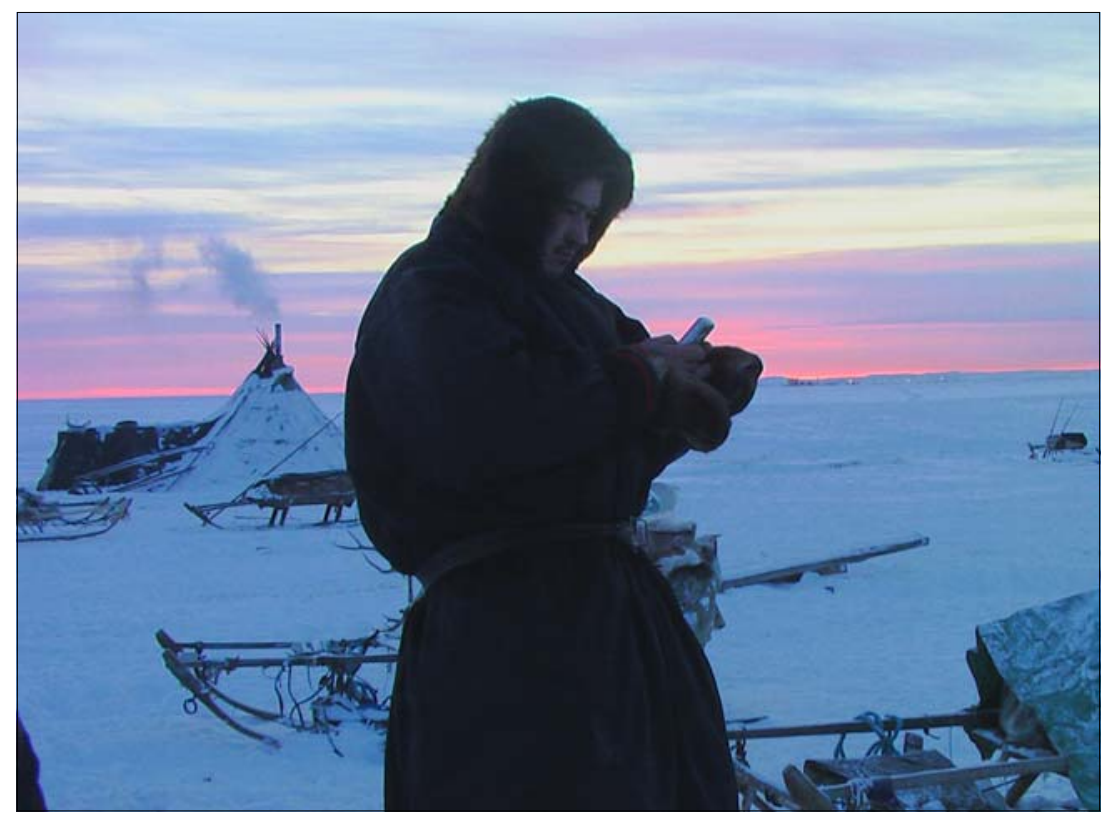

Figure 2. At attempt to send an MMS from Varandei tundra. 
clude what the consequences of these changes are for their everyday herding and fishing practices. Therefore, indigenous monitoring of environmental performance has been among the main points in negotiating coexistence between tundra economy and the extractive industry (Stammler \& Wilson 2006).

In October 2007, Semen, reindeer herder in camp 2, managed the herd along the pipeline between Myadsei and Toboi. There he saw a pipeline leak, which formed a lake of oil under it. He used his mobile phone to record a video of the leakage, with a voice-over of the exact location, size of the oil lake formed, and other crucial information. The footage he planned to send to the chairman of the herding cooperative, who would then deliver the message on to the oil company. However, the chairman's phone was not MMS compatible, so the information had to be transferred by a voice call. While some companies specifically encourage such indigenous monitoring of pipelines (Sibneft 2004: 14), in this case the company firmly opposed the effort, even confiscating the phone and forcing the herder to delete one of his videos. Nonetheless, there is much potential of mobile communication technology for the benefits of indigenous livelihoods.

Nomads of the tundra have always been highly adaptive and have responded flexibly to any changes happening in their environment. They are in a good position to do so because of their mobile lifestyle (Stammler 2005) which they had before the mobile phone, whereas sedentary city-communities feel that the mobile phone enables their flexibility and a new kind of nomadic way of life (Geser 2004: 20ff, 40). Therefore the use of the mobile phone's features beyond voice communication will probably spread fast among tundra nomads, as camera and video phones, MMS and the like are becoming more accessible.

Among other features, the SMS might acquire a particular position for several reasons: SMS is a non-verbal form of communication, which I think will become very popular in societies in Siberia, where many indigenous people prefer non-verbal communication to verbal. This is similar to Finland, where I have experienced a definite preference of SMS to voice calling. This became evident on my first New Year's Eve in Rovaniemi, Finland, where large parts of the crowd waiting for fireworks outdoors at midnight started to write text messages to friends and relatives, instead of calling them, let alone communicating with other people standing next to them. It was an enacted culture of silence that highly impressed me and made me think about the extended use of the mobile phone and its implications. I would suggest that in other societies with an emphasis on a culture of silence, such as in the Russian North, if not the circumpolar North, we may see similar developments that make the mobile phone socially important as a tool of communication that extends the verbal sphere, and yet allow expression of emotions, for instance, through the 
application of 'emoticons' (smileys, etc). On the more practical side, SMS is convenient because the message gets delivered whenever the phone of the recipient is switched on and in network coverage. So the sender and receiver do not need to be connected at exactly the same time.

\section{DISCUSSION}

After having outlined the basic fieldwork evidence, we shall explore how this material relates to theories of technological change and in inter-regional comparison. In particular, I shall focus on the questiosn in which aspects does the mobile phone influence nomadic societies differently from sedentary settings, and where we can identify general patterns?

While the generalisations mentioned below by no means present results of a thorough investigation with a significant sample size, we see trends in mobile phone use very similar to existing user profiles that have been identified for other societies. In this sense, reindeer nomads are not very different from sedentary societies in the West (Lemish \& Cohen 2005a) and in Russia (Vershinskaia 2002, Gladarev 2006).

- Young men seem to be the most active drivers of mobile phone use. They are interested in the technical capacities of the handsets and make use of mobile phones far beyond immediate telecommunication. The handsets are used for leisure activities too, such as playing games, sending and downloading music, shooting photos and videos. Young men were also very active in teaching their fathers' generation how to use mobile phones and what they are good for. Therefore, technologically sophisticated mobile phones have entered the tundra also as a symbol of prestige.

- Middle-aged men have started to use mobile phones for their work, as well as for networking with relatives. I have heard them holding business-related talks with their herding cooperative headquarters, talking with neighbours about timing of migrations, pasture use, slaughter and other issues, and with oil company employees to negotiate barter and food supplies.

- Different to that, young and middle-aged women present a user group that uses mobile phones more for leisure purposes. An important function seems to be exchanging news and gossiping with neighbours in the tundra as well as with relatives in town. Younger women were also active in downloading and exchanging ringtones and playing games, some- 
times together with young men. For these women the outer appearance of the handsets was very important, with colours of pink, red and turquoise dominating, and phones with in-built mirror were preferred. Gladarev (2006) reports a very similar taste in phones among young women in St Petersburg.

On the one hand, these results might be seen as confirming the theory of Apparatgeist by Katz and Aakhus (2002a) stating that there are universal principles in the relation of people and technology. On the other hand, these general user characteristics can also be seen all over the globe, as a result of massive promotion of user roles by mobile phone operators and handset producers themselves. For example, Nordic mobile operators fund and promote research into these user profiles, which then feed back into advertisement campaigns and contribute to spreading these universal characteristics. ${ }^{9} \mathrm{I}$ have found myself being laughed at twice by Varandei herders because of my mobile phone: in 2006 - just seven months after the mobile phone had been introduced in their area - because my handset was sovsem ustarevshii ('totally outdated'), and in 2007 because my handset was a 'female phone', because of its form and the mirror on the back side. Within a very short time, commonly valid views and values had entered the Nenets nomadic society in Varandei, a process of value homogenisation or cultural integration that so far had been associated with the spread of television programmes to remote corners of the globe (Hoffmann-Novotny 1993). Some authors ask if the spread of the mobile phone may be culturally and socially more significant than the spread of television (Katz \& Aakhus 2002b: 4ff). For reindeer herders in the North I would argue that it is indeed, as for a life on the move the mobile phone is much easier to accommodate than television sets, which require elaborate antenna systems and more power supply.

Figure 3. Domestic use of mobile phones by women.

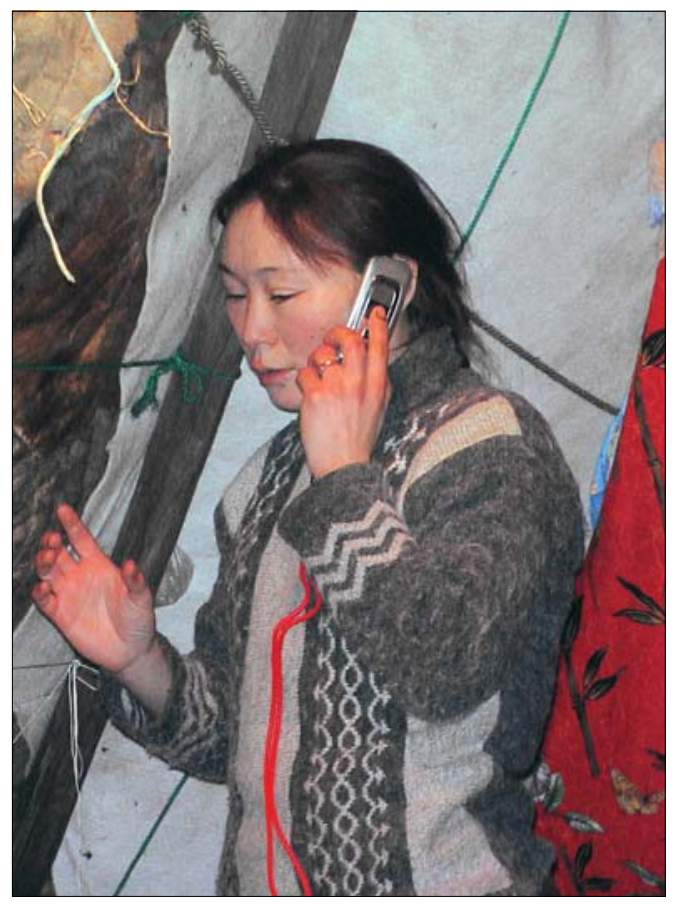


The fact that the young generation is the driving force behind this innovation is not surprising, and it is a phenomenon that has been noted everywhere with different forms of technological change with almost any kind of device or gadget from the snowmobile to the mobile phone. On the other hand, Geser (2004: 6) notes that the mobile phone creates a new equality in the society because of its popularity "irrespective of age, gender, cultural background, wealth, income or hierarchical position". This finding is also confirmed in the tundra, where I have seen girls and boys playing with phones together, chatting, and elders and youngsters watching photographs, talking and exchanging information.

Nonetheless the preliminary user groups outlined above suggest these slight differences that still make gender and generation important as variables for the kind of action that is performed with the mobile phone and its social significance, as well as for the aspect of fashion and status. While for the snowmobile the gendered bias and the role of young men played a crucial role, and we could say that "Hi-tech = Guy-tech" (Selwyn 2007), the same author rightly argues that with modern communication technologies gendered perspectives are more to be found in details and the popularity spreads more evenly across different groups of the population. The finding that traditional gendered perceptions, stereotypes and gender- and generation-specific uses of mobile phones are important factors of the mobile phone age (e.g., as argued in Lemish \& Cohen 2005a for Israel, and Gladarev (2006) for St Petersburg) should therefore be acknowledged to refine Geser's (2004) argument on equality. The trends in fashion, taste and status of the mobile phone that are globally reinstated by phone producers and network operators help to underline these differences, and have spread to reindeer herders in Varandei and young girls in Tel Aviv alike.

The benefits of mobile phones are increasingly felt by people even in areas not yet connected to the network, so we might conceptualise the Russian North currently divided into areas with and without mobile coverage. This is especially true for people who travel to cities and come back to their homelands outside the catchment area. This leads to some inequality, which might possibly increase in the future. As Fondahl (1998: 104-107) has mentioned, Evenki in Zabaikal'e spend massive amounts of time and resources to travel to a village for some information just to find that the holder of that information is not in town, so that they have travelled in vain. For this travel, people there and elsewhere would use the snowmobile, conditions permitting, but in many cases fuel is not available in remote locations, even when people have a snowmobile. Paradoxically, in one of the worlds' richest areas of oil and gas deposits, the shortage of fuel has hampered the use and diffusion of snowmobiles signifi- 
cantly, and is among the reasons why the snowmobile have not revolutionised the Russian North as much as it did the North American or Fennoscandian.

In this respect the mobile phone is much easier to accommodate. Similar experience is reported from the Philippines, refining the argument that not only the presence or absence of phones, but also connection rates are crucial to facilitate information flow. In traditional Filipino settlements (barangay) in 2002, even though mobile phones had already arrived, people still used to travel in vain to visit or make business trips in town just to find out that the people who they needed to meet were not present. Connection charges were too prohibitive and people did not have cash to pay for them (Strøm 2002).

I would underline the significance of prices with the example of Yamal reindeer herders, who do not have mobile phone coverage except around the village of Yar Sale. All over the rest of the peninsula, they could theoretically use satellite phones, but the price of the handset as well as connection charges and quality are not comparable to GSM mobile phones. Satellite phones are only used by some selected camps that were provided with the handsets by the administration, industrial companies, or other rich organisations. Unfortunately, a satellite phone operator was chosen with bad coverage for the northernmost areas of the globe (Globalstar), so that incoming researchers' Iridium phones with their better coverage were in high demand. With the equivalent of a three-minute phone call for a kilogram of meat sold on the market, it becomes understandable why satellite phones have remained a niche-product for the wealthier part of the community.

Even though the area covered by mobile phones in the Russian North is increasing, the inequality between regions with and without coverage will remain stable for years to come. This is because mobile networks develop there under two conditions: in larger population centres, or in the vicinity of large industrialisation projects. Unlike land line providers, mobile phone operators are commercial companies which need a critical mass of customers to make their investments worthwhile. This critical mass is not present in the sparsely populated Russian North. However, the example of the Khanty-Mansyisk and the Nenets Autonomous Okrug has shown that mobile coverage comes as a cumulative add-on to industrial development in remote areas even without large permanent settlements. Therefore, the areas where tundra or taiga dwellers will stay without mobile coverage are far away from larger settlements and far away from industrial development. There will be less of these areas in the future, but they will remain.

The changing perception of time is another point worth discussing on the basis of the herders' observations and discourse about their use of mobile phones 
for planning, coordinating contacts and business. ${ }^{10}$ The loss of the element of surprise of a visit on the one hand, and the comfort of a ready meal on the other hand - both mentioned by herders -, exemplify the effect of planning security after a mobile phone call in the everyday lives of reindeer herders. On a more general level, if the use of mobile phones for these purposes becomes dominant, it is likely that the whole pace of life will change. This will be an effect specific to a nomadic community and different from urban sedentary settings, as I shall show below. Vershinskaia (2002: 144) quotes an informant in an urban Russian setting mentioning that the "speed of life has changed", in connection with the statement that mobile phones allow for mobility in an urban setting and mobility being perceived as a sign of success and prosperity.

The same prestige of mobility lies at the basis of nomadic lifestyle in Yamal (Stammler 2005), with the difference that this was the case centuries before the advent of new technology. According to Geser $(2004: 4,40)$ the mobile phone enables its user to reduce 'idle' time to an absolute minimum, for example, waiting without doing anything. Any 'unused' minute can be filled by talking, making business, getting news, accessing the Internet, etc. Reindeer herders not exposed to mobile phones emphasize, however, how important time is for surviving on the tundra. Even if they are not engaged in anything, the time that they spend watching their environment is not "unused". The different pace is one of the features that make life in the tundra for reindeer herders so different from the life in villages:

Here, we have no fixed timetable of getting up, having our meals, going to bed. There is no nachal'nik ['boss'], who can tell us what and how to work. Our days are organised by the needs of our reindeer. As long as they are well, we have all the freedom in the world to live how we want (Konstantin Tusida, Tambey tundra, 2001).

This independence is one of the main advantages of a life on the tundra as mentioned by herders. Another distinct feature related to time is the almost proverbial saying that "there is no hurry in the tundra", or "you must not hurry in the tundra".

When mobile phones reduce "idle" time in the tundra, the pace of village or urban life may get transferred to the tundra, and nomads there may start hurrying, making unnecessary or even fatal mistakes, and eventually lose the freedom that many of them so highly appreciate.

Geser (2004) has noted that mobile phones make social life highly volatile, unpredictable, and disorganised. This is also associated with what is seen as a new form of nomadism generated by the use of mobile phones. According to Kopomaa (2000), the mobile phone has accelerated people's experience of free- 
dom as a result of this unpredictability, or what he conceptualises as increased "elasticity" of life, consisting of "approximate" moments instead of the "precise moments" of the pre-mobile phone society. This is indicative of a new "nomadic social participation" (Geser 2004: 21) among sedentary city-dwellers, particularly the young generation: Teens and young adults use the device to tie together their peer group against the backdrop of a relatively nomadic life (Ling 2002: 4).

The mobile phone for the first time established communication between moving individuals in cities. In the Russian tundra, the situation seems to be different, and moving individuals have been the norm for centuries prior to the invention of mechanised transport. Among Russian nomads it seems that mobile phones do not accelerate the experience of freedom, but they reduce it: planning security increases, moments are stated more precisely, and life becomes less "elastic". Among nomads of the tundra, any visitor could come any time and would get accommodation and food - such is the "law of the tundra" (Stammler 2005). Reindeer herders would more or less know which visitors they might expect in which season. With the mobile phone, this is cemented into more predictable and precise plans by previously announcing dates or even times.

We therefore conclude preliminarily that in sedentary societies mobile phones may create space for a new form of nomadism, freedom, and flexibility, whereas among nomadic pastoralists they do the opposite, tighten the grip on people's life rhythm, and reduce freedom and flexibility. Differently from citynomads, tundra-nomads did not need mobile phones to become mobile and express their freedom, and nomadism is not a "backdrop" but the basis of people's life, their relationships and their natural and spiritual environment. Therefore, the influence on the pace of life and the perception of time will alter the social texture of nomadic space.

\section{SUMMARY AND CONCLUSIONS}

This article looked at the influence of technological change on nomads in the Russian North, using two crucial innovations as examples, the snowmobile and the mobile phone. I have shown that the snowmobile did not have the same revolutionary impact on the Russian tundra as it did in Fennoscandia

- because the distances are much longer;

- infrastructure and spare parts are only available in villages or towns that are often hundreds of kilometres away from pastures; 
- fuel is hardly available or, if at all, at a very high price; and

- herders had already been using sitting transport for herd control for centuries, so the advance was not from walking to driving like among the Sámi, but from driving to driving.

I have argued that the snowmobile has already generated social change in the tundra, even though it might not be crucial for the economy in many places. For example, even though there are women driving snowmobiles, this is considered a rare exception, and it is particularly the male youth who extensively use snowmobiles for visiting neighbouring camps, towns and villages, going to parties - and eventually finding spouses. However, it has not (yet?) significantly diminished the prestige and the cultural and economical importance of the reindeer harness. Unlike what Pelto has described about Finnish Lapland, trained reindeer still figure prominently in exchange networks in the tundra and for the bride price (Stammler 2005:176ff). Reindeer races are still the king's discipline in the yearly sports competitions, for which herders train all year long. Ironically, for winning a reindeer race herders often get a snowmobile as the main award.

On the other hand, I have shown that even though we stand at the very beginning of a 'mobile phone revolution' in the tundra, mobile phones have the potential for a greater penetration into nomadic societies because

- mobile phones are cheaper, and, unlike snowmobiles, are not likely to lead to internal stratification;

- they are low or zero maintenance and do not need expensive spare parts;

- they are light and easy to take along, and do not require carrying additional load for a nomadic household;

- they require minimal energy that can be provided even in cold climate settings; and

- they connect people not only to their neighbours, as do snowmobiles, but theoretically to the rest of the world, with huge implications.

Because of these characteristics, the mobile phone is especially well suited to smoothly integrate into the existing economic, social and cultural settings, which explains the exceptionally fast diffusion worldwide. Evidence from the Arctic Russian nomadic pastoralists seems to confirm this finding. Some social consequences of mobile communication seem to be generally uniform all over the globe, such as trends of fashion and its being a status symbol, confirming the universalist argument by Katz and Aakhus (2002a). Differences in gender 
and generation also seem to be emphasised by the use of mobile phone among reindeer nomads in ways similar to people in urban sedentary settings.

While the snowmobile has changed the society, leading to increased social stratification and division between the wealthy and the poor (Helander-Renvall 2007), cheaper mobile phones did not have this dividing effect, because in catchment areas everybody could afford these. However, I have argued that the inequality among people in the Russian North in the future will be rather between regions with and without network coverage.

Most tundra people have emphasised the benefits that they see from the use of mobile phones. I suggest that the analysis should include the extended capacities of the mobile phone in the future, with features such as photo and video sharing, MMS, Internet, SMS, fashion, jewellery and other uses, not all of which are directly connected to the mobile phone's basic character as a tool for voice communication. A good example of this would be a reindeer herder monitoring pipeline leakages on his pastures over his phone. This also shows the potential of the mobile phone to revolutionise the networking of Arctic Russian nomads with the global indigenous movement - a process that is now beginning in a region where seven years ago there was no connection with the outside world except for the telegraphs of meteorological stations. The consequences of this development are similar to other societies that skipped the level of landline connectedness and stepped from intra-community communication straight into the global information age.

I have also suggested some points where the influence of mobile phones is specific to a nomadic setting. Here the 'information age' is different from a 'global knowledge society'. Sending and receiving information through short calls or text messages does not substitute the in-depth knowing that tundra and taiga nomads need to carry on their mobile life. Mobile phones bring a way of communication to the tundra that was originally associated with spiritual beings and shamans only. I argued that especially the non-verbal uses of the mobile phone, such as SMS fit well to societies where silence is an important cultural quality. This communication, however, does not replace the need for skills of acting in the environment that evolve only out of practice on the land. If the practice of spreading news through physical movement will significantly diminish, this will affect people's knowing of the land as well. Moreover, mobile phones seem to have a different effect on the perception of time and the change of pace in life among nomadic tundra and taiga dwellers.

Tundra nomads have always displayed a high level of curiosity to the new, and a high level of agency in embedding innovations into their existing way of life (Stammler 2002). This is the background for the overall positive judge- 
ment of the mobile phone in the tundra. For reindeer herders, its advantages seem to be more directly obvious than, for example, those of the GPS. Satellite navigation has entered the tundra at a similar time, the devices are not more expensive, some herders have it, but it is not used very often. In everyday life the added value of the GPS for herders is rather small. However, as single technological devices are becoming more versatile in the future, the navigation function might become another add-on to reindeer herders' mobile phones. We stand only at the very beginning of the mobile phone revolution.

\section{ACKNOWLEDGEMENT}

The author acknowledges the generous support for the research by the Max Planck Institute for Social Anthropology, the EU BALANCE project, and the ENSINOR (Decision no. 208147) and BOREAS MOVE-INNOCOM (Decision no. 118702) projects of the Finnish Academy. Thanks to Elina Helander-Renvall, Terhi Vuojala-Magga, Anna Stammler-Gossmann and Mare Kõiva for their comments at various stages.

\section{NOTES}

1 From personal conversations with the Sámi politicians and herders Johan Matis Turi in Kautokeino, May 2007, and Pekka Aikio in Södänkylä, May 2007.

2 Thanks to Sergei Baryshnikov for his research on the advent of radio communication in the tundra, and his good memory of the extension of mobile phone coverage in rural areas.

3 Thanks to Mr Guy Pépin from the Bombardier Museum in Valcourt, Québec, Canada for information on the Ski-Doo Alpine 640.

${ }^{4}$ Thanks to Terhi Vuolaja-Magga for explaining the practice of herding on skis among pre-snowmobile Sámi. Dogs were used then to round up the herd, guided by people on skis. This makes a greater difference to the snowmobile than transport on reindeer. As a result, the use of dogs for herding has heavily decreased, and only recently seems to be on the rise again.

${ }^{5}$ For western readers it is worth noting that the Russian/Soviet Buran snowmobiles have no shock absorbers.

6 Thanks to Vladislav Peskov for providing background information about the spread of mobile communication in the Nenets Autonomous Okrug. 
7 'Erv' is Nenets for 'master' of the land, (Russian: khoziain), the name of the first private herders' union that separated from a Soviet kolkhoz. The union became well known for its special relation with the oil industry in the 1990s (Stammler \& Peskov 2008: 836, 838).

8 Nenets for 'life', the name for the first private reindeer herder community on the Yamal Peninsula. Obshchina is a community of indigenous people practicing traditional subsistence activities on the land, and was after 2000 recognised by Federal Russian legislation. For history, definition and an ethnographic portrait of this community, see Stammler 2005b. The most recent information came from chairman Mikhail Okotetto from personal conversation in 2008.

${ }^{9}$ Norwegian company Telenor seems to be particularly active and has funded significant research, quoted in Ling 2004, Geser 2004, as well as the study on St Petersburg by Gladarev (2006).

${ }^{10}$ I thank my wife Anna Stammler-Gossmann for pointing to this aspect of the discussion.

\section{REFERENCES}

Beach, Hugh 1981. Reindeer-Herd Management in Transition: The Case of Tuorpon Saameby in Northern Sweden. Uppsala Studies in Cultural Anthropology 3. Uppsala.

Beach, Hugh \& Stammler, Florian 2006. Human Animal Relations in Pastoralism. In: F. Stammler \& H. Beach (eds.) Humans and Reindeer on the Move: Special Issue of Nomadic Peoples. Vol. 10, No. 2, pp. 6-30.

Collective authors, Novosti Yugry 2000. Toporom pravo ne zashitish. 21 November. Available at http://www.hmao.wsnet.ru/people/priroda.htm, last accessed on 15 April 2002.

Fondahl, Gail A. 1998. Gaining Ground? Evenkis, Land, and Reform in Southeastern Siberia. Cultural Survival Studies in Ethnicity and Change. Boston: Allyn and Bacon.

Geser, Hans 2004. Towards a Sociology of the Mobile Phone. Sociology in Switzerland: Sociology of the Mobile Phone. Online Publications. March 2004 (Release 3.0). Zurich: Institute for Sociology, University of Zurich. Available at http://socio.ch/ mobile/t_geser1.pdf, last accessed on 15 Feb 2008.

Giddens, Anthony 1986. The Constitution of Society: Outline of the Theory of Structuration. Berkeley: University of California Press.

Gladarev, Boris 2006. Zhenshchina, muzhchina i mobil'nyi telefon. Sotsiologicheskie Issledovania. Vol. 4, pp. 68-76.

Golovnev, Andrei V. 1995. Govoriashchie kul'tury. Traditsii samodiitsev i ugrov. Ekaterinburg: Ural Branch, Russian Academy of Sciences.

Helander-Renvall, Elina 2007. Logical Adaptation to Modern Technology - Snowmobile Revolution in Sápmi. The Borderless North. Proceedings of the Fourth NRF Open Meeting, Oulu \& Tornio, Finland and Haparanda \& Luleå, Sweden, 2007. First Theme: Tech-Knowledgy and Its Applications, pp. 27-33. 
Hoffmann-Nowotny, Hans Joakim 1993. Weltmigration - Eine soziologische Analyse. In: W. Kälin \& R. Moser (eds.) Migrationen aus der Dritten Welt: Ursachen-Wirkungen-Handlungsmöglichkeiten. Bern, Stuttgart: Paul Haupt, pp. 57-68.

Horst, Heather A. \& Miller, Daniel 2005. The Cell Phone: An Anthropology of Communication. Oxford: Berg Publishers.

Ingold, Tim 2000. The Perception of the Environment: Essays in Livelihood, Dwelling and Skill. London \& New York: Routledge.

Katz, James E. \& Aakhus, Mark (eds.) 2002a. Perpetual Contact. Mobile Communication, Private Talk, Public Performance. Cambridge: Cambridge University Press.

Katz, James E. \& Aakhus, Mark 2002b. Conclusion: Making Meaning of Mobiles A Theory of Apparatgeist. In: J. E. Katz \& M. Aakhus (eds.) Perpetual Contact. Mobile Communication, Private Talk, Public Performance. Cambridge: Cambridge University Press, pp. 301-318.

Kemp, William B. 1971. The Flow of Energy in a Hunting Society. Scientific American. Vol. 225, No. 3, pp. 105-115.

Khariuchi, Galina P. 2001. Traditsii i innovatsii v kul'ture nenetskogo etnosa (vtoraia polovina XX veka). Tomsk: Tomsk University Publishers.

Khazanov, Anatoly M. 1994. Nomads and the Outside World. (2nd edition.) Madison: University of Wisconsin Press.

Konstantinov, Yulian \& Vladimirova, Vladislava 2006. The Performative Machine: Transfer of Ownership in a Northwest Russian Reindeer Herding Community (Kola Peninsula). In: F. Stammler \& H. Beach (eds.) Humans and Reindeer on the Move. Special Issue of Nomadic Peoples. Vol. 10, No. 2, pp. 166-186.

Kopomaa, Timo 2000. The City in Your Pocket: Birth of the Mobile Information Society. Helsinki: Gaudeamus.

Krupnik, Igor 1993. Arctic Adaptations: Native Whalers and Reindeer Herders of Northern Eurasia. Hanover: University Press of New England.

Krupnik, Igor \& Vakhtin, Nikolai 2002. In the "House of Dismay": Knowledge, Culture and Post-Soviet Politics in Chukotka, 1995-1996. In: E. Kasten (ed.) People and the Land. Pathways to Reform in Post-Soviet Siberia. Berlin: Dietrich Reimer Verlag, pp. 7-43.

Ksentofontov, Ivan 2007. Lyzhi iskali motor... Moto. No. 1. Available online at http:// moto.zr.ru/articles/51747/, last accessed on 18 Feb 2008.

Lemish, Dafna \& Cohen, Akiba A. 2005a. On the Gendered Nature of Mobile Phone Culture in Israel. Sex Roles. Vol. 52, Nos. 7/8, pp. 511-521.

Lemish, Dafna \& Cohen, Akiba A. 2005b. Tell Me about Your Mobile and I'll Tell You Who You Are: Israelis Talk about Themselves. In: R. Ling \& P. Pedersen (eds.) Mobile Communications: Renegotiation of the Social Sphere. London: Springer, pp.187-202.

Ling, Rich 2002. The Social and Cultural Consequences of Mobile Telephony as Seen in the Norwegian Context. Telenor R\&D Report R9, 2002. Oslo: Telenor.

Ling, Rich \& Pedersen, Per E. (eds.) 2005. Mobile Communications: Renegotiation of the Social Sphere. London: Springer.

Nawfus, Dawn \& Tracey, Karina 2002. Mobile Phone Consumption and Conceptions of Personhood. In: J. E. Katz \& M. Aakhus (eds.) Perpetual Contact. Mobile Com- 
munication, Private Talk, Public Performance. Cambridge: Cambridge University Press, pp. 206-221.

Niglas, Liivo \& Toulouze, Eva 2004. Yuri Vella's Worldview as a Tool for Survival: What Filming Reveals. Pro Ethnologia. Vol. 17, pp. 95-114.

Pelto, Pertti J. 1987. The Snowmobile Revolution. Technology and Social Change in the Arctic. Prospect Heights, Illinois: Waveland Press.

Rees, W. Gareth, Stammler, Florian M. \& Danks, Fiona S. \& Vitebsky, Piers 2008. Vulnerability of European Reindeer Husbandry to Global Change. Climatic Change. Vol. 87, Nos. 1-2, pp. 199-217. First online edition available at http:// www.springerlink.com/content/j2k1r1j1775r603p/fulltext.pdf, accessed in Feb 2008 .

Samakhova, Irina 2001. S toporom protiv "Lukoila”. Obshaia Gazeta, 22 February, quoted in Skvazhina, Nezavisimoe neftianoe obozrenie. Available at http:// www.nefte.ru/crime/krim67.htm, last accessed on 16 April 2002.

Selwyn, Neil 2007. Hi-tech = Guy-tech? An Exploration of Undergraduate Students' Gendered Perceptions of Information and Communication Technologies. Sex Roles. Vol. 56, Nos. 7-8, pp. 525-536.

Sibneft 2005. 2004 Report on Social Responsibility. OAO Sibneft.

Stammler, Florian 2002. Success at the Edge of the Land: Present and Past Challenges for Reindeer Herders of the West-Siberian Yamalo-Nenets Autonomous Okrug. Nomadic Peoples. Vol. 6, No. 2, pp. 51-71.

Stammler, Florian 2005. Reindeer Nomads Meet the Market: Culture, Property and Globalisation at the "End of the Land". Halle Studies in the Anthropology of Eurasia. Vol. 6. Münster: LIT Publishers.

Stammler, Florian 2005b. The Obshchina Movement in Yamal: Defending Territories to Build Identities? In: E. Kasten (ed.) Rebuilding Identities: Pathways to Reform in Postsoviet Siberia. Siberian Studies series. Berlin: Dietrich Reimer Verlag. Vol. 3, pp. 109-134.

Stammler, Florian \& Peskov, Vladislav 2008. Building a 'Culture of Dialogue' among Stakeholders in North-West Russian Oil Extraction. Europe-Asia Studies. Vol. 60, No. 5 (July), pp. 831-849.

Stammler, Florian \& Wilson, Emma 2006. Dialogue for Development: An Exploration of Relations between Oil and Gas Companies, Communities and the State. In: E. Wilson \& F. Stammler (eds.) Special issue on the Oil and Gas Industry, Local Communities and the State. Sibirica. Vol. 5, No. 2, pp. 1-42.

Strøm, Georg 2002. The Telephone comes to a Filipino village. In: J. E. Katz \& M. Aakhus (eds.) Perpetual Contact. Mobile Communication, Private Talk, Public Performance. Cambridge: Cambridge University Press, pp, 274-283.

Wajcman, Judy 2007. The Cell Phone in the Hands of a Jamaican. Review of The Cell Phone: An Anthropology of Communication by H. Horst \& D. Miller, 2006. Metascience, Vol. 16, No. 3, pp. 493-495.

Ventsel, Aimar 2004. Sakha Pop Music and Ethnicity. In: E. Kasten (ed.) Properties of Culture - Culture as Property. Pathways to Reform in Post-Soviet Siberia. Siberian Studies. Berlin: Dietrich Reimer Verlag, Vol. 2, pp. 67-85. 
Vershinskaia, Olga 2002. Comunicación móvil como fenómeno social: La experiencia rusa. [Mobile Communication as a Social Phenomenon: The Russian Experience]. Revista De Estudios De Juventud. Vol. 57, pp. 139-149.

Vitebsky, Piers 1995. From Cosmology to Environmentalism: Shamanism as Local Knowledge in a Global Setting. In: R. Fardon (ed.) Counterworks: Managing the Diversity of Knowledge. London: Routledge, pp. 182-203.

Vitebsky, Piers 2000. Coping with Distance: Social, economic and environmental change in the Sakha Republic (Yakutia), Northeast Siberia. Report. Scott Polar Research Institute, University of Cambridge.

Vitebsky, Piers 2002. Withdrawing from the Land. Social and Spiritual Crisis in the indigenous Russian Arctic. In: C. M. Hann (ed.) Postsocialism. Ideals, Ideologies and Practices in Eurasia. London: Routledge, pp. 180-195.

Vitebsky, Piers 2005. Reindeer People. Living with Animals and Spirits in Siberia. London: Harper Collins.

Ziker, John P. 2002. Peoples of the Tundra. Northern Siberians in the Post-Communist Transition. Illinois: Waveland Press. 